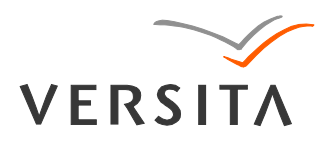

VERSITA
GEOCHRONOMETRIA 38(4) 2011: 314-324

DOI 10.2478/s13386-011-0044-3

Available online at

www.springerlink.com

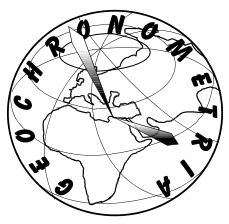

\title{
RADIOCARBON METHOD IN MONITORING OF FOSSIL FUEL EMISSION
}

\author{
ANDRZEJ Z. RAKOWSKI ${ }^{1,2}$ \\ ${ }^{I}$ Radiocarbon Laboratory, GADAM-Center of Excellence, Silesian University of Technology, Gliwice, Poland. \\ ${ }^{2}$ Leibniz-Labor für Altersbestimmung und Isotopenforschung, Chrisian-Albrecht-Universität zu Kiel, Kiel, Deutschland.
}

Received 28 February 2011

Accepted 25 May 2011

\begin{abstract}
The traditional radiocarbon method widely used in archaeology and geology for chronological purposes can also be used in environmental studies. Combustion of fossil fuels like coal, natural gas, petroleum, etc., in industrial and/or heavily urbanized areas, has increased the concentration of carbon dioxide in the atmosphere. The addition of fossil carbon caused changes of carbon isotopic composition, in particular, a definite decrease of ${ }^{14} \mathrm{C}$ concentration in atmospheric $\mathrm{CO}_{2}$ and other carbon reservoirs (ocean and terrestrial biosphere), known as the Suess effect. Tree rings, leaves, as well as other annual growing plants reflected the changes of radiocarbon concentration in the atmosphere due to processes of photosynthesis and assimilation of carbon from the air. By measuring radiocarbon concentration directly in atmospheric $\mathrm{CO}_{2}$ samples and/or biospheric material growing in industrial and/or highly urbanized areas where high emission of dead carbon is expected, it is possible to estimate the total emission of dead $\mathrm{CO}_{2}$. Based on equations of mass balance for $\mathrm{CO}_{2}$ concentration, stable isotopic composition of carbon and radiocarbon concentration it is possible to calculate $\mathrm{CO}_{2}$ concentration associated with fossil fuel emission into the atmosphere. The procedure use differences between the radiocarbon concentration and stable isotope composition of carbon observed in clean areas and industrial or/and highly urbanized areas.
\end{abstract}

Keywords: Radiocarbon, Suess effect, stable isotopes of carbon, AMS.

\section{INTRODUCTION}

The increase of combustion of fossil fuels like coal, natural gas, petroleum etc. in industrial areas, causes the emission of carbon dioxide to the atmosphere. Isotopic composition of fossil carbon is slightly different from modern carbon, mostly because the former does not contain radiocarbon whose half-life is much shorter than the formation period of fossil fuels.

First investigations of contemporary tree samples (Suess, 1955) proved that their radiocarbon activity was lower than in samples from the middle of the $19^{\text {th }}$ century. Atmospheric $\Delta{ }^{14} \mathrm{C}$ has decreased by about $20.0 \%$

Corresponding author: A. Z. Rakowski

e-mail: arakowski@leibniz.uni-kiel.de between years 1890 and 1950 from which $17.3 \%$ is attributed to the Suess effect and the remainder is thought to be caused by variation in the cosmic ray production of radiocarbon (Stuiver and Quay, 1981). 95\% of the total carbon dioxide from burning of fossil fuels is released in the Northern hemisphere (NH). However, because of airmass mixing between Northern $(\mathrm{NH})$ and Southern $(\mathrm{SH})$ hemispheres, the Suess effect has a global character.

Precise investigations in atmospheric concentration of carbon dioxide have been performed at Mauna Loa Observatory in Hawaii (Keeling and Whorf, 1994) since 1956. Data from the three Antarctic cores DE08, DE08-2 and DSS (Etheridge et al., 1996) and direct measurement from Mauna Loa (Keeling and Whorf, 1994) were used to reconstruct the past atmospheric carbon dioxide concen- 
tration from 1000 to 1992 . The results show that concentration of this gas in the atmosphere maintained constant level of about 280 ppmV between years 1000 and 1880 . These results were also used to estimate the amount of carbon in the atmosphere before the Suess effect. The total amount of carbon in the atmosphere before $1880 \mathrm{had}$ a value of $\mathrm{N}_{0}=615 \mathrm{GtC}$ (Keeling et al., 1989). Between 1880 and 1990, the concentration of carbon dioxide in the atmosphere has increased by about $90 \mathrm{ppmV}$. In present time, the total concentration of this gas is about $370 \mathrm{ppmV}$ and is higher than that observed at any time within the last 400,000 years (Petit et al., 1999). The increasing rate of carbon dioxide concentration in the atmosphere is proportional to the emission rate of carbon dioxide from fossil fuel consumption. In less than two centuries, $280 \mathrm{Gt}$ of carbon has been added to atmosphere from burning of fossil fuels (Marland et al., 1999).

In the late 1950s and early 1960s radiocarbon concentration in the atmosphere rapidly increased due to nuclear bomb tests. The excess radiocarbon from nuclear detonations was mostly injected into the northern stratosphere and through mid- to high- latitude tropopause gap returned to the northern troposphere. As a result of this process in 1963 the level of radiocarbon concentration in Northern hemisphere (NH) was about $100 \%$ higher than pre-bomb concentrations. Maximum level of radiocarbon concentration in Southern hemisphere (SH) was lower (only $70 \%$ of natural concentration) than in $\mathrm{NH}$ and was observed in 1965 (Nydal and Lövseth, 1996). Since the test ban treaty was enforced in 1963, the radiocarbon concentration in the atmosphere slowly decreased, due to carbon exchange between the carbon reservoirs (mainly ocean and biosphere). As bomb radiocarbon reached a global equilibrium in the late 1960s (Telgadas, 1971), there have not been large differences between radiocarbon concentrations between the $\mathrm{NH}$ and $\mathrm{SH}$ from 1970 onwards (Hua and Barbetti, 2004). The large pulse of artificial radiocarbon injected to the atmosphere gave us a powerful tool for studying the carbon cycle and transfer processes between the carbon reservoirs (Nydal, 1968, Oeschger et al., 1975, Levin and Hessheimer, 2000).

Data of $\mathrm{CO}_{2}$ and radiocarbon concentration level are constantly collected in clean and polluted areas, either directly for atmospheric air (Levin et al., 1994, 1999, 2003, Levin and Kromer, 1997, 2004, Schmidt et al., 2003, GLOBALVIEW-CO2, 2008 Kuc et al., 2003), or for plants (McNeely, 1994, Muraki et al., 1998, 2001, Rakowski et al., 2001, 2004a, b, 2005, 2008, 2010, Rakowski, 2010) by several laboratories around the world. To estimate the local decrease of radiocarbon concentration due to the Suess effect and $\mathrm{CO}_{2}$ emission mathematical equations can be used that include a relationship between carbon isotope composition and $\mathrm{CO}_{2}$ concentration from fossil fuel combustion and the decreasing trend of radiocarbon content over time (Levin et al., 2003). The method, which was used for calculation of
$\mathrm{CO}_{2}$ concentration from fossil fuel use, will be presented in detail in this paper.

\section{SAMPLES AND METHOD}

Samples were taken from annual growth rings in pine trees using hollow drills. To obtain sufficient material for AMS analysis, three core samples were taken from each tree and annual growth rings were separated. Each core taken was $25-30 \mathrm{~cm}$ long and had $0.5 \mathrm{~cm}$ in diameter. Samples were washed in distilled water and prepared with the widely used A-A-A method. Some of the samples were treated to extract $\alpha$-cellulose from early and late wood ring using a method described in Green (1963) and Pazdur et al. (2005).

Pre-treated residues of samples were combined with cupric oxide and sealed into glass tubes evacuated with a rotary pump. The tubes were then placed in an electric furnace for 2 hours at $850^{\circ} \mathrm{C}$. Carbon dioxide produced from the samples was purified in a glass cryogenic vacuum-line system. Water produced during combustion was removed via a trap containing a mixture of methanol and liquid nitrogen at $170 \mathrm{~K} . \mathrm{SO}_{\mathrm{x}}$ compounds were removed with an n-pentane trap cooled to $77 \mathrm{~K}$ by liquid nitrogen. Purified $\mathrm{CO}_{2}$ was then condensed in glass tubes using liquid nitrogen.

The prepared carbon dioxide samples were reduced to graphite using iron powder as a catalyst (Kitagawa et al., 1993). The iron powder was prepared in a vacuum line containing hydrogen and heated for about 1 hour at $450^{\circ} \mathrm{C}$. The line was evacuated and carbon dioxide was condensed with the iron powder using liquid nitrogen. Hydrogen was then added and the glass tube was sealed. Reduction was done in an electric furnace at $850^{\circ} \mathrm{C}$ for 6 hours.

The resulting mixture of graphite and iron powder was dried and pressed into a target holder for AMS ${ }^{14} \mathrm{C}$ measurements with a HVEE 3.0 MV Tandetron AMS system at Nagoya University (Nakamura et al., 2000). Each target was measured for $30 \mathrm{~min}$ in each of three analyses. The ${ }^{12} \mathrm{C}^{3+}$ and ${ }^{13} \mathrm{C}^{3+}$ currents were kept at 190 and $200 \mathrm{nA}$, respectively. Typical counting rate for NBS HOxII standard samples is about $60 \mathrm{cpm}$. The stable carbon isotope ratio was measured using a Finningan MAT 252 isotope-ratio Mass Spectrometer at the Center for Chronological Research, Nagoya University (Nakamura et al., 2000). Radiocarbon contents are reported as $\Delta{ }^{14} \mathrm{C}$ in per mil (\%o) deviations from the standard sample, 0.7459 activity of NBS oxalic acid (SRM-4990C) (Stuiver and Polach, 1977) and the stable carbon isotope ratio is expressed in $\delta^{13} \mathrm{C}_{\mathrm{VPDB}}$ (Craig, 1957). For age correction and correction for isotopic composition formulas presented in Mook and Plicht (1999) were used:

$\Delta^{14} \mathrm{C}=\left(\frac{\mathrm{A}_{\mathrm{SN}} \mathrm{e}^{\lambda(\mathrm{y}-\mathrm{x})}}{\mathrm{A}_{\mathrm{abs}}}-1\right) \cdot 1000 \%$, 


$$
A_{a b s}=0.7459 A_{O x}\left(1-\frac{2\left(25+\delta^{13} C\right)}{1000}\right) e^{\lambda(y-1950)},
$$

where

$\mathrm{A}_{\mathrm{SN}}$ : radiocarbon activities in the sample,

$\mathrm{A}_{\text {abs }}$ : absolute activities of oxalic acid standard (HoX-II) whose $\delta^{13} \mathrm{C}$ was normalized to $-25 \%$ and corrected for radioactive decay from 1950 to the measurement year (y), $\mathrm{A}_{\mathrm{Ox}}$ : measured activities for oxalic acid standard,

$\mathrm{x}$ : year of growing,

$y:$ year of measurement,

$\lambda$ : decay constant for radiocarbon.

\section{RESULTS AND DISCUSSION}

\section{Kraków - NH zone 1}

Kraków $\left(50^{\circ} 3^{\prime} \mathrm{N}, 19^{\circ} 54^{\prime} \mathrm{E}\right)$ is a city of about one million people, located about $100 \mathrm{~km}$ to the north of the Tatra Mountains in southern Poland (Fig. 1). Air pollution related to the urban infrastructure, industrial facilities, and a large steel factory (Steel factory - Huta im. Tadeusza Sendzimira) have caused elevated carbon dioxide levels in the local atmosphere (Kuc et al., 2003). Annual tree rings samples from pine tree (Pinus sylvestris) growing near the university were taken, using a hollow drill.

Since 1983, the Department of Environmental Physics, University of Science and Technology in Kraków has monitored carbon isotope compositions in tropospheric $\mathrm{CO}_{2}$ (Kuc and Zimnoch 1998). Samples of atmospheric $\mathrm{CO}_{2}$ were taken at biweekly intervals from the Faculty building roof on the university campus, $25 \mathrm{~m}$ above ground level (T. Kuc, personal communication). Data of radiocarbon concentration in atmospheric $\mathrm{CO}_{2}$ for the city of Kraków were corrected for isotopic composition of carbon $\left(\delta^{13} \mathrm{C}=-25 \%\right)$ to provide $\Delta{ }^{14} \mathrm{C}$ notification, and were used to estimate the growing period of pine tree in southern Poland. The estimated growing period for Scots pine (Pinus sylvestris) in southern Poland is from early April to late September (see Fig. 2), and was determined by comparing the concentration of radiocarbon in annual tree rings with the average concentration of radiocarbon in atmospheric $\mathrm{CO}_{2}$ calculated for different periods.

To calculate the differences in radiocarbon concentration levels between "clean air" and urban area of Kraków, data from Schauinsland (Germany) were used (Levin and Kromer, 2004). All data show a continuous decrease in radiocarbon activity over time. An average year to year decrease of $7.3 \pm 1.8 \%$ per year for tree ring data and $9.2 \pm 3.3 \%$ o per year for atmospheric radiocarbon concentration ware obtained for the analyzed period.

Differences in $\Delta^{14} \mathrm{C}$ values in tree rings and atmospheric carbon dioxide from Kraków are presented in Fig. 2. Radiocarbon concentrations in atmospheric $\mathrm{CO}_{2}$ at Kraków show strong peak-to-peak ( $\sim 56 \%$, Kuc and Zimnoch, 1998) and seasonal fluctuations that cannot be observed in tree ring measurements. Radiocarbon concentrations in both kinds of samples from Kraków are lower than those in "clean air" at the Schauinsland station. This can be attributed to a local Suess effect. To compare, the $\Delta{ }^{14} \mathrm{C}$ values found in tree rings were $108.7 \pm 3.5 \%$, $99.8 \pm 3.6 \%$ and $85.3 \pm 3.5 \%$ for years 1994,1995 and 1996 , respectively. These values are lower than the yearly mean values in atmospheric $\mathrm{CO}_{2}$ at Schauinsland (117\%o, $111 \%$ and $102 \%$; Levin and Kromer, 2004), but higher than those measured in Zagreb (annual average - 81\%, $88 \%$ and 56\%; Krajcar-Bronić et al., 1998) for the same

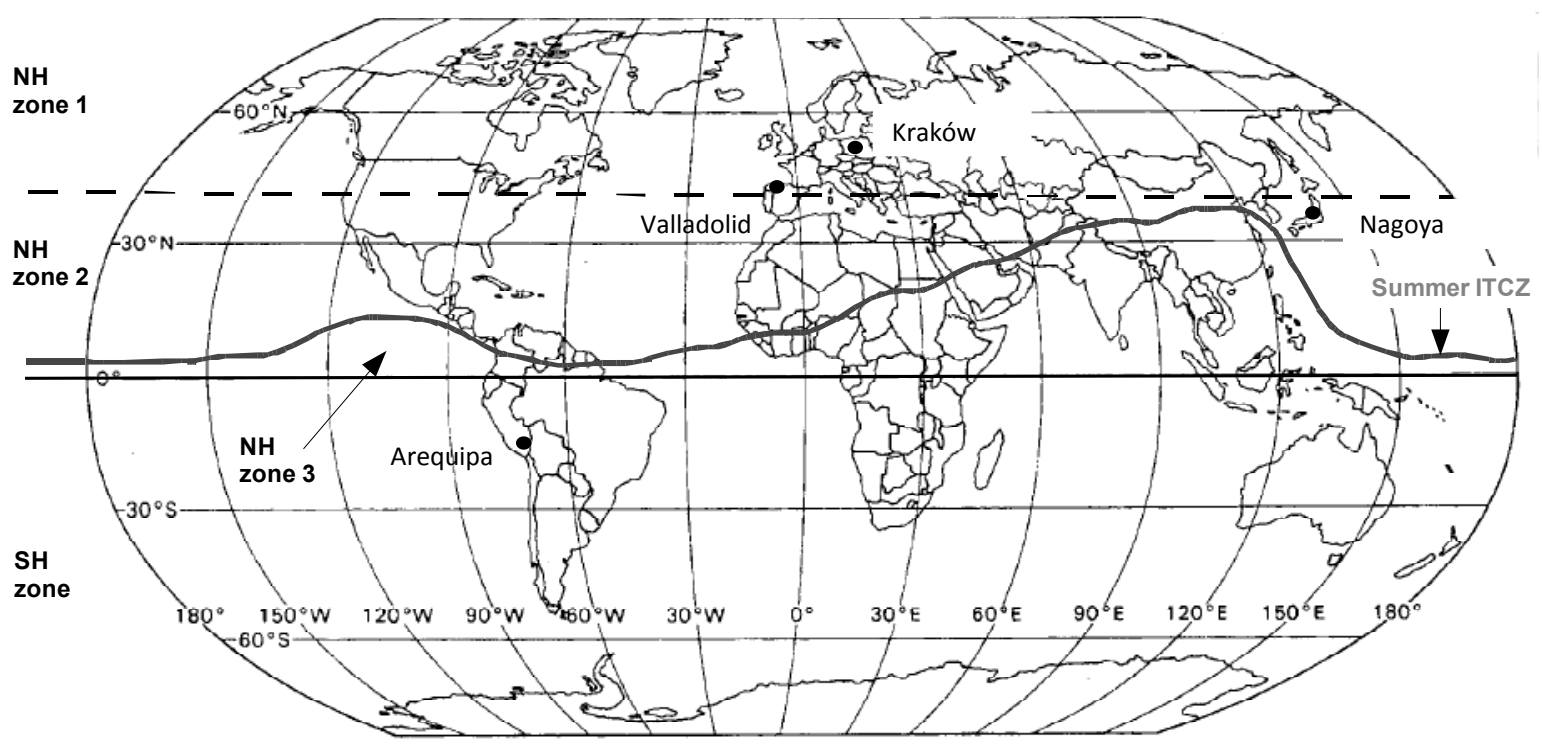

Fig. 1. Location of sample collection sites on the World map showing the areas covered by NH zones 1, 2, 3, and SH zone. The position of the summer ITCZ (Intertropical Convergence Zone) adopted from Linacre and Greets (1997). After Hua and Barbetti (2004). 


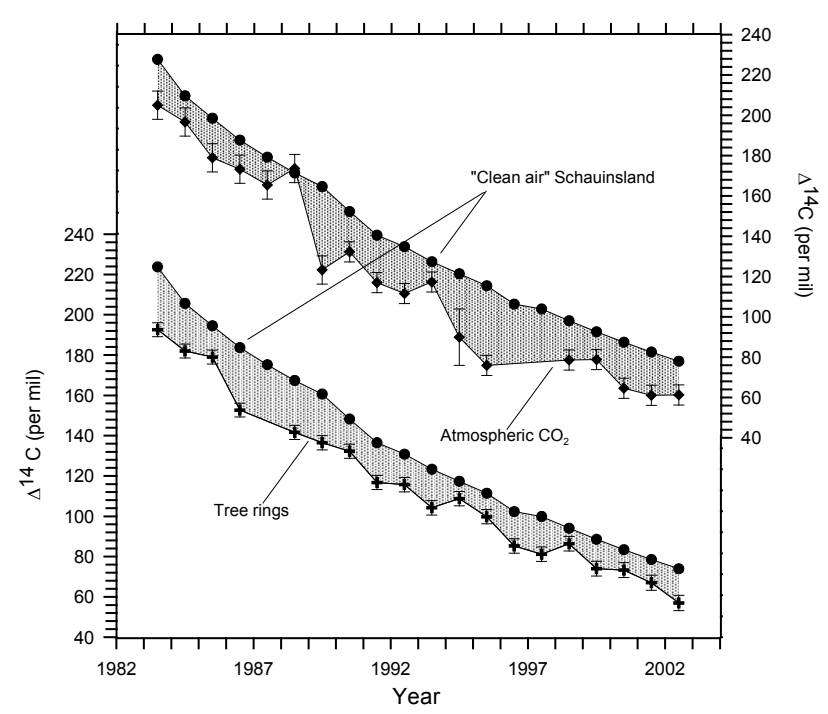

Fig. 2. Radiocarbon concentration in atmospheric $\mathrm{CO}_{2}$ (Kuc et al., 2003) and tree rings (Pinus sylvesrtis) samples collected at Kraków, Southern Poland. Radiocarbon concentration in atmospheric $\mathrm{CO}_{2}$ at Schauinsland station (Levin and Kromer, 2004) represents "clean air". All atmospheric data represent mean value for the period between April and September corrected by $\delta^{13} \mathrm{C}=-25 \%$.

period. Since the growing period does not cover the whole year, the amount of $\mathrm{CO}_{2}$ from domestic use for heating during the winter, are not taken into account in the values derived from tree rings, which results in higher values being observed in Zagreb. Radiocarbon concentration in Niepołomice (Pazdur et al., 2007), about $20 \mathrm{~km}$ east from Kraków, are comparable with those observed in "clean air" from Schauinsland, suggest that the Suess effect has strictly local character.

Exponential curves were fitted to the Kraków data for the period 1983-2002 to determine long-term changes in radiocarbon concentration in the atmosphere and biosphere, giving the correlation coefficient $\mathrm{R}$ of 0.98 for tree rings and 0.95 for atmospheric $\mathrm{CO}_{2}$ data. These analyses provide time decay constants of $16.70 \pm 0.22 \mathrm{yr}$ for tree ring data and $14.31 \pm 0.20 \mathrm{yr}$ for atmospheric $\mathrm{CO}_{2}$ data, and differ from $18.70 \pm 0.15 \mathrm{yr}$ estimates reported in the literature (Levin and Kromer, 1997). Decreasing ratios calculated from linear data-fitting gave values of $6.75 \pm 0.29 \%$ o per year for tree ring data and $7.75 \pm 0.53 \%$ o per year for atmospheric $\mathrm{CO}_{2}$ data. According to the prediction of the linear model, the radiocarbon concentration should have reached the natural level of $\Delta{ }^{14} \mathrm{C}=0 \%$ in 2007 (atmospheric $\mathrm{CO}_{2}$ ) and in year 2010 (tree rings), comparable with the estimates of 2007 for Schauinsland (Levin and Kromer, 1997), 2004 for Groningen (Meijer et al., 1995) and 2000 for Zagreb (Krajcar-Bronić et al., 1998).

Changes of $\delta^{13} \mathrm{C}$ values in annual tree rings from Kraków for the period 1983-2002 are presented in Fig. 3. The values are in the range between $-27.5 \%$ to $-25.4 \%$, and correspond to the values listed for the $\mathrm{C} 3$ cycle

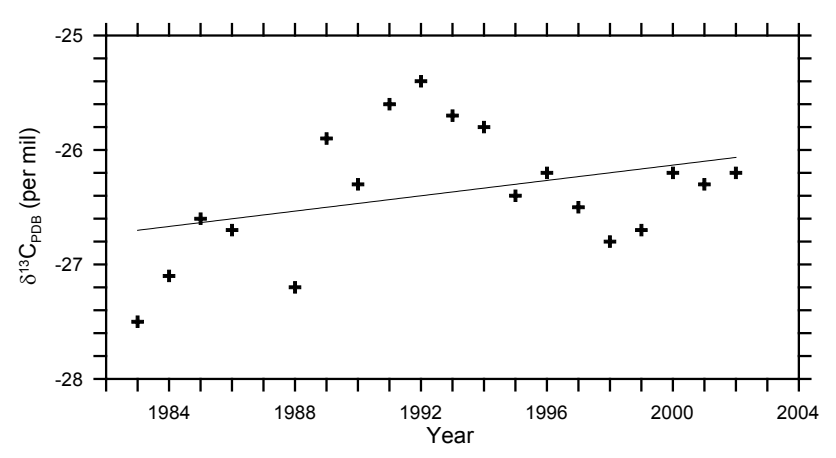

Fig. 3. Stable isotope composition of carbon in tree rings (Pinus sylvestis) from Kraków, southern Poland. $\delta^{13} C_{P D B}$ measurement error is $\pm 0.1 \%$.

plants. A linear slight increase of $0.03 \%$ per year was noted for the whole period between years 1983 and 2002. However, the $\delta^{13} \mathrm{C}$ values increase systematically during the period between 1983 and $1992(0.198 \pm 0.043 \%$ oper year), than decrease between 1993 and 1998 ($0.221 \pm 0.028 \%$ per year), and finally start to increase for the rest of the analyzed period $(0.160 \pm 0.050 \%$ per year $)$. Kuc and Zimnoch (1998) noted a decrease of $\delta^{13} \mathrm{C}$ values of $-0.02 \%$ per year, for the period 1983-1995, as a result of increase of $\mathrm{CO}_{2}$ concentration from natural gas use, for which $\delta^{13} \mathrm{C}$ is $-54.4 \%$.

\section{Valladolid - NH zone 2}

${ }^{14} \mathrm{C}$ concentration in tree rings (early wood (EW) and late wood (LW)) from Valladolid is presented in Fig. 4, together with data representing average radiocarbon concentration as reference values. The monthly average temperature in Valladolid for each month of the year being higher than $0^{\circ} \mathrm{C}$ (Agencia Estatal de Meterología (AEMet)) permits to make the assumption that the growing period for a pine tree can be extended for the whole year. The average temperature in the coldest months of the year (January and February) for the period between years 1971 and 2000 are $4.0^{\circ} \mathrm{C}$ and $6.1^{\circ} \mathrm{C}$ respectively.

In order to compare results obtained for tree rings (EW, LW) data from Schauinsland (Levin and Kromer, 2004) represent summer average (April-September, $(\mathrm{EW})$ ) and winter average (October-March, (LW)) for corresponding year were used. $\Delta^{14} \mathrm{C}$ concentrations for 2004-2007 period were estimated by extrapolation on the curves. All data show a gradual decrease of ${ }^{14} \mathrm{C}$ concentration over time. Decrease of $6.2 \pm 1.3 \%$ per year for tree rings was obtained for the period between 1986 and 2007. Atmospheric and tree ring $\Delta{ }^{14} \mathrm{C}$ values measured in Kraków during similar period (1983-2002) decrease at rates $9.2 \pm 3.3 \%$ per year and $7.3 \pm 1.8 \%$ per year, respectively (see above), while data from 2 stations in Croatia show decrease rate $12 \%$ per year (Zagreb) and 10.6\% per year (Plitovice) (Krajcar-Bronić et al., 1998).

Radiocarbon concentrations in tree ring samples (EW and LW) from Valladolid, in the whole period between 
1986 and 2007, are lower than in "clean air" at the Schauinsland station, which is attributed to a local Suess effect. For example, the $\Delta^{14} \mathrm{C}$ values in tree rings from Valladolid of $167.3 \pm 3.2 \%$ EW, $153.4 \pm 3.3 \%$ EW and $139.2 \pm 3.2 \%$ EW and $166.7 \pm 3.3 \%$ LW, $160.3 \pm 3.2 \%$ o LW, 144.9 $\pm 3.2 \%$ LW, for 1987, 1988 and 1989, respectively are significantly lower than the mean summer values in maple tree leaves from Quebec $(221 \%$, $211 \%$ and 194\%, respectively, (McNeely, 1994)), but higher than those observed for tree rings in Krakow (this work) and Nagoya (this work) in whole period.

Differences between radiocarbon concentration $\left(\Delta^{14} \mathrm{C}\right)$ in EW and LW for each year are presented in Fig. 4b. Average difference between $\Delta{ }^{14} \mathrm{C}$ values in $\mathrm{EW}$ and LW of $-1.8 \pm 1.3 \%$ for the whole period of 1986-2007 was observed, suggesting values higher during summer (LW) than winter $(\mathrm{EW})$ period. Based on the previously made assumption that growing period for Valladolid spans months from January to December, the EW rings are

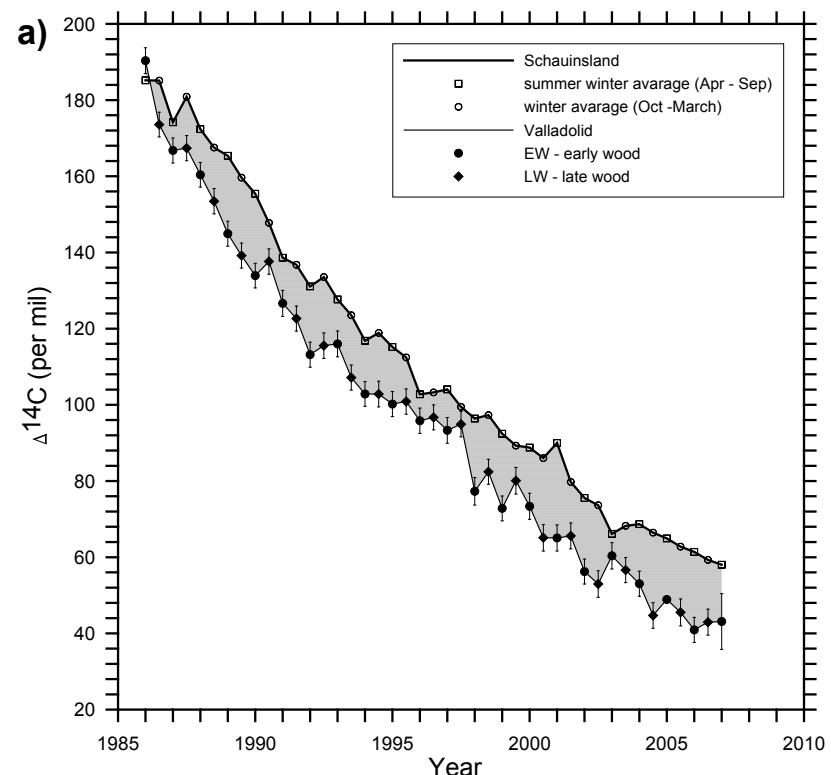

b)

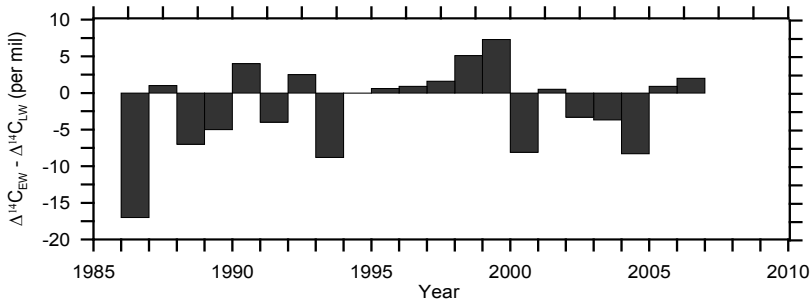

Fig. 4. a) Changes of radiocarbon concentration in tree ring (Pinus pinea L.) samples at Valladolid, central Spain. Upper solid line represents radiocarbon concentration $\left(\Delta^{14} \mathrm{C}\right)$ at Schauinsland station (Levin and Kromer, 2004). Values for the period between 2004 and 2007 were calculated from exponential curve fitted to the observed data for Schauinsland, b) Differences in radiocarbon concentration in early wood (EW, $\left.\Delta^{14} C_{E W}\right)$ and late wood $\left(L W, \Delta^{14} C_{L W}\right)$ at each year, during the period between 1986-2006. forming in the first half of the year including the coldest months of January and February (Agencia Estatal de Meterología (AEMet)). Assuming that the emission of $\mathrm{CO}_{2}$ from the local traffic has a constant value in each month, lower $\Delta^{14} \mathrm{C}$ values observed in $\mathrm{EW}$ are related to the increase of $\mathrm{CO}_{2}$ emission from domestic use (i.e. gas heaters, gas stoves). For the period between years 1995 and 1999 radiocarbon concentration in EW rings is higher than in LW rings. The average temperatures in January and February are higher than the average temperatures for those months for the last 30 years (1971-2000, Agencia Estatal de Meterología (AEMet)). Those values are $5.3^{\circ} \mathrm{C}$ (1995), $6.7^{\circ} \mathrm{C}(1996), 4.5^{\circ} \mathrm{C}(1997), 5.6^{\circ} \mathrm{C}$ (1998) for January, and $6.9^{\circ} \mathrm{C}(1995), 9.3^{\circ} \mathrm{C}(1996), 7.9^{\circ} \mathrm{C}(1997)$, $14.3^{\circ} \mathrm{C}$ (1998) for February. This can be the reason of lower emission of $\mathrm{CO}_{2}$ from heating installations during the winter time.

To estimate long-term changes of radiocarbon concentration exponential function was fitted to the results obtained for tree rings from Valladolid, giving the correlation coefficient $\mathrm{R}$ of 0.984 . These analyses provide time decay constants of $13.02 \pm 0.19 \mathrm{yr}$ for tree rings, which is shorter than $18.70 \pm 0.15 \mathrm{yr}$ estimates reported in the literature (Levin and Kromer, 1997). In additional, a linear function was fitted to the $\Delta{ }^{14} \mathrm{C}$ data for the whole period 1986-2007 giving the decreasing rate of $6.64 \pm 0.21 \%$ per year. Linear data-fitting predicts 2015 as a year that $\Delta^{14} \mathrm{C}$ values will be equal to $0 \%$, comparable with reported values (see above).

Fig. 5 presents temporal changes of $\delta^{13} \mathrm{C}$ values in annual rings of pine tree (Pinus pinea L.) from Valladolid. The values are in the range between $-24.2 \%$ and $33.6 \%$, and correspond to the values listed for the $\mathrm{C} 3$ cycle plats. A linear decrease of $-0.24 \pm 0.04 \%$ o per year was noted for the whole period between years 1986 and 2007, as a consequence of emission of $\mathrm{CO}_{2}$ from natural gas (domestic emission) and gasoline (traffic emission) use.

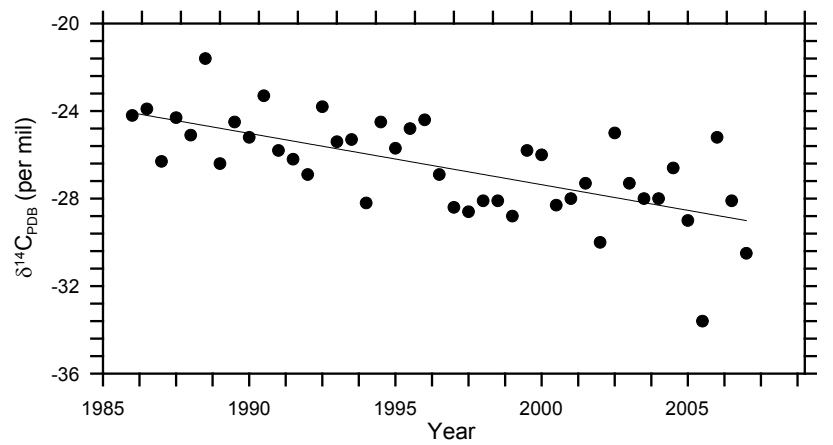

Fig. 5. Stable isotope composition of carbon in tree rings (Pinus pinea L.) from Valladolid, central Spain. $\delta^{13} C_{P D B}$ measurement error is $\pm 0.1 \%$. 


\section{Nagoya - NH zone 2}

Fig. 6 shows the variation of ${ }^{14} \mathrm{C}$ concentrations in tree rings for the period of 1951 to 2002 (Nagoya A), and for the period 1982 to 2003 (Nagoya B). Data representing average radiocarbon concentration in $\mathrm{NH}$ zone 2 (Hua and Barbetti, 2004) are included to represent annual average values of ${ }^{14} \mathrm{C}$ concentration in "clean air". The annual average values were used instead of seasonal averages, according to mild and maritime climate in Nagoya, which extends the vegetation period for pine trees to almost the whole year. The average temperatures for the coldest months (January and February) are above $0^{\circ} \mathrm{C}$ (Japan Meteorological Agency (JMA)).

Results show a gradual decrease of radiocarbon activity over time. An average decrease rate of $15.2 \pm 2.1 \%$ per year (Nagoya A) for the period between 1968 and 2002, and for the period between 1985 and 2003 the values for Nagoya A and Nagoya B are $6.8 \pm 1.5 \%$ per year and $8.2 \pm 1.3 \%$ per year, respectively. Atmospheric $\Delta{ }^{14} \mathrm{C}$ data measured at two stations in Croatia (Zagreb and Plitovice) during a similar period yielded decreasing values of $12 \%$ and $10.6 \%$ per year respectively (KrajcarBronić et al., 1998). For Schauinsland station, decreases of $14.1 \%$ per year for the period 1983-1985 and 9.7\%o per year for 1985-1989 were obtained (Levin et al., 1992).

Radiocarbon concentrations in annual rings of the pine tree from Nagoya are lower than those observed in "clean air" of relevant years for $\mathrm{NH}$ zone 2 (Hua and Barbetti, 2004). This can be attributed to a local Suess effect. The $\Delta{ }^{14} \mathrm{C}$ values of $55.4 \pm 3.3 \%$ o, $48.7 \pm 3.2 \%$ and

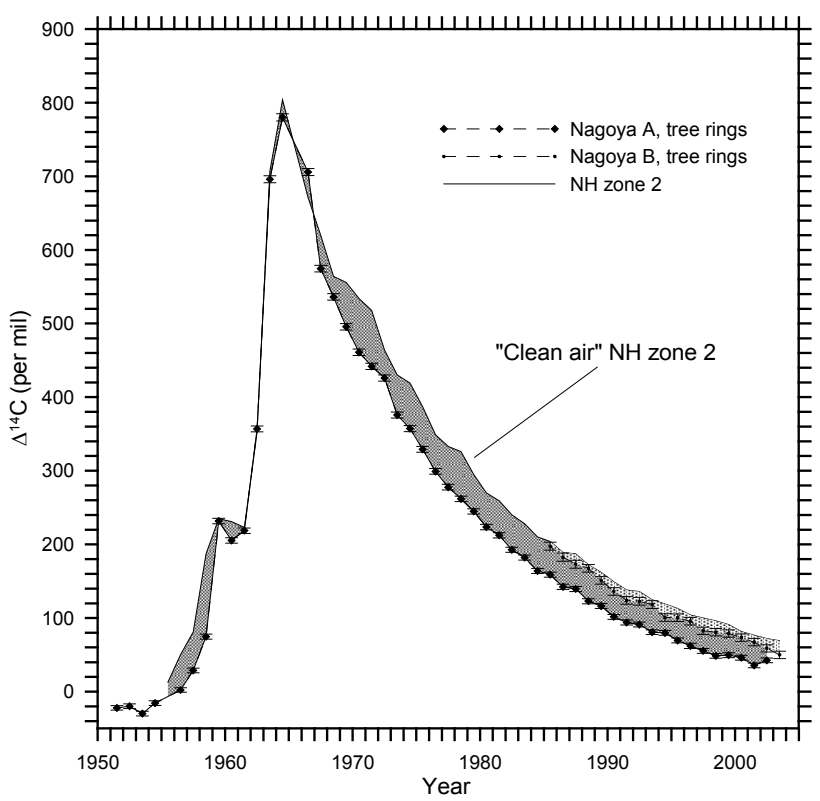

Fig. 6. Changes of radiocarbon concentration in tree rings (Pinus densiflora) samples at Nagoya (a. Nagoya A, b. Nagoya B), central Japan. Solid line represents mean radiocarbon concentration $\left(\Delta^{14} \mathrm{C}\right)$ for Northern Hemisphere (NH) zone 2 (Hua and Barbetti, 2004).
49.5 $\pm 3.2 \%$ obtained for 1997, 1998 and 1999 (Nagoya A) annual rings of the pine tree, respectively, are slightly lower than those for leaves of a tree (Quercus variabilis) collected nearby (N3, 64.1 $\pm 3.5 \%, \quad 54.3 \pm 3.2 \%$ and $63.2 \pm 3.3 \%$, Muraki et al. 2001) for respective years. This is possibly due to different values of $\mathrm{CO}_{2}$ emission from fossil fuel and vegetation period between those two kinds of trees used for the experiments. For Nagoya B, values of $82.6 \pm 5.6 \%$ o (1997), $80.6 \pm 5.0 \%$ o (1998) and $78.9 \pm 5.0 \%$ o (1999) were observed and are higher than data obtained by Muraki et al. (2001) for N4, 70.8土 3.3\%o (1998) $66.7 \pm 3.2 \%$ o (1999).

To estimate long-term changes in radiocarbon concentration, exponential functions were fitted to the results for tree rings from Nagoya, giving the correlation coefficient $\mathrm{R}$ to be 0.99 . The functions yield an inverse value of the decay constant to be $11.92 \pm 0.16 \mathrm{yr}$ and $14.16 \pm 0.20 \mathrm{yr}$, comparable to the estimates of around 16yr reported in the literatures (Levin and Kromer, 1997, Krajcar-Bronić et al., 1998, McNeely, 1994). In addition, a linear function was fitted to the $\Delta^{14} \mathrm{C}$ data for the periods 1979-1983 and 1984-2002, separately, and the $\Delta^{14} \mathrm{C}$ value was estimated to decrease at a rate of $15.6 \pm 2.5 \%$ per year and $7.5 \pm 2.3 \%$ o per year (Nagoya A), respectively. The value of 7.7 $\pm 1.8 \%$ o per year was obtained for the period 1985 2003 for Nagoya B. Atmospheric $\Delta{ }^{14} \mathrm{C}$ values measured at two stations in Croatia (Zagreb and Plitovice) during a similar period yielded decreasing rates of $12 \%$ per year and 10.6\% per year, respectively (Krajcar-Bronić et al., 1998). Similarly, for Schauinsland station, decreasing rates were obtained to be $14.1 \%$ per year and $9.7 \%$ per year for the periods $1983-1985$ and $1985-1989$, respectively (Levin et al., 1992). The decreasing rates in $\Delta^{14} \mathrm{C}$ at four different places show similar values for similar periods. This suggests that the process of diluting ${ }^{14} \mathrm{C}$ concentration in the atmospheric $\mathrm{CO}_{2}$ could have a similar character in different locations and environments. The linear regressions predict that $\Delta^{14} \mathrm{C}$ values should be reach natural value in 2006 for Nagoya A and 2010 for Nagoya B, comparable with the estimates of 2007 for Schauinsland (Levin and Kromer, 1997), 2004 for Groningen (Meijer et al. 1995) and 2000 for Zagreb (Krajcar-Bronić et al., 1998).

Fig. 7 shows temporal changes of $\delta^{13} \mathrm{C}$ values in annual rings of pine tree (Pinus densiflora L.) from Nagoya. The values are in the range between $-29.5 \%$ and $-24.6 \%$, and correspond to the values listed for the $\mathrm{C} 3$ cycle plants. A slight linear increase of $0.024 \pm 0.004 \%$ per year was noted for the whole period between years 1951 and 2001 for Nagoya A, and decrease of $-0.080 \pm 0.004 \%$ per year for Nagoya B was observed for the period 19852003. Since there are no data representing isotopic composition of carbon in atmospheric $\mathrm{CO}_{2}$ from Nagoya, it is difficult to explain the observed discrepancy. 


\section{Arequipa - SH zone}

Fig. 8 shows radiocarbon concentration between years 1986 and 2001 in tree rings of pine tree (Pinus radiata) from Arequipa, Southern Perú. Radiocarbon concentration in "clean air" representing year average values for the Southern Hemisphere (SH) zone was taken from Hua and Barbetti (2004).

Results show a gradual decrease in radiocarbon activity over time. A decrease of $6.9 \pm 1.2 \%$ per year for the tree rings data was obtained for the period analyzed. Atmospheric $\Delta{ }^{14} \mathrm{C}$ data measured at Pretoria (South Africa, after Hua and Barbetti, 2004) and average values of radiocarbon concentration in Southern Hemisphere zone (Hua and Barbetti, 2004) during a similar period yielded decreasing values of $10.5 \%$ and $8.8 \%$ per year, respectively.

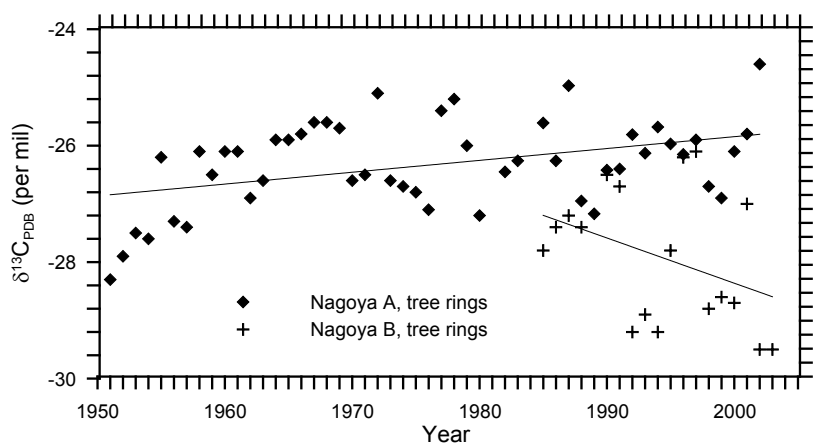

Fig. 7. Stable isotope composition of carbon in tree rings (Pinus densiflora) from Nagoya, central Japan. $\delta^{13} C_{P D B}$ measurement error is $\pm 0.1 \%$.

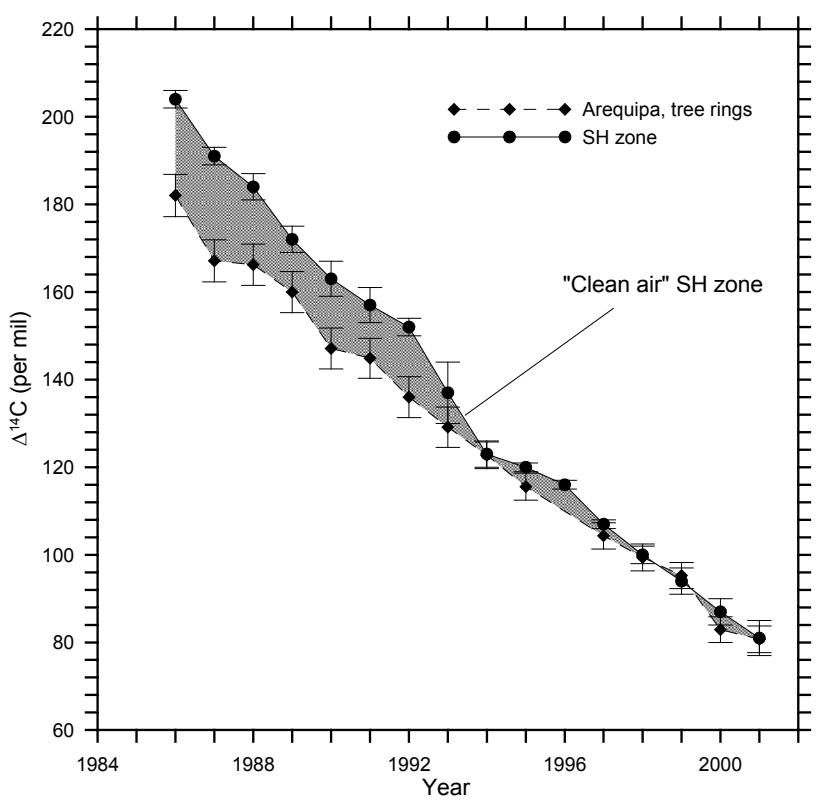

Fig. 8. Changes of radiocarbon concentration in tree rings (Pinus radiata) from Arequipa, Southern Peru. Solid line represents trend of the radiocarbon concentration in "clean air" for Southern Hemisphere (SH) zone (Hua and Barbetti, 2004).
Radiocarbon concentration in annual tree rings of pine tree from Arequipa are lower than those observed in Pretoria and Cape Grim but are also lower than average radiocarbon concentration for Southern Hemisphere zone (Hua and Barbetti, 2004). This can be attributed to a local Suess effect.

To estimate long-term changes in radiocarbon concentration, an exponential function was fitted to the observed data, giving the correlation coefficient $\mathrm{R}$ of 0.93 . The function yields an inverse value of the decay constant to be $18.82 \pm 0.18 \mathrm{yr}$, which corresponds well to the $\sim 16 \mathrm{yr}$ reported in literature (Levin and Kromer, 1997, McNeely 1994, Krajcar-Bronić et al., 1998). In addition, a linear function was fitted to the $\Delta^{14} \mathrm{C}$ data for the period 19862001 giving the decreasing rate of $6.57 \pm 0.15 \%$ per year. Linear data-fitting predicts 2015 as a year that $\Delta^{14} \mathrm{C}$ values will be equal to $0 \%$, comparable with reported data (see above).

Fig. 9 shows temporal changes of $\delta^{13} \mathrm{C}$ values in annual rings of pine tree (Pinus radiata) from Arequipa. The values are in the range between $-24.6 \%$ and $-21.7 \%$, and correspond to the values listed for the $\mathrm{C} 3$ cycle plants. A slight linear decrease of $-0.05 \pm 0.04 \%$ o per year was noted for the whole period between years 1985 and 2001. However, for the period between years 1986 and 1992 , an increase of $0.35 \pm 0.03 \%$ o per year can be observed.

\section{FOSSIL FUEL COMPONENT $c_{\text {foss }}$}

The radiocarbon method is widely known as a method for chronological study but can also be useful for environmental purposes. Radiocarbon concentration in atmosphere changes due to the emission of dead $\mathrm{CO}_{2}$ from fossil fuel use. Due to this process, the concentration of radiocarbon has decreased over time. This can be observed not only in the atmosphere but also in other reservoirs of carbon (biosphere and ocean). Tree rings, leaves as well as other annual growing plants reflect the changes of radiocarbon concentration in the atmosphere due to processes of photosynthesis and assimilation of carbon

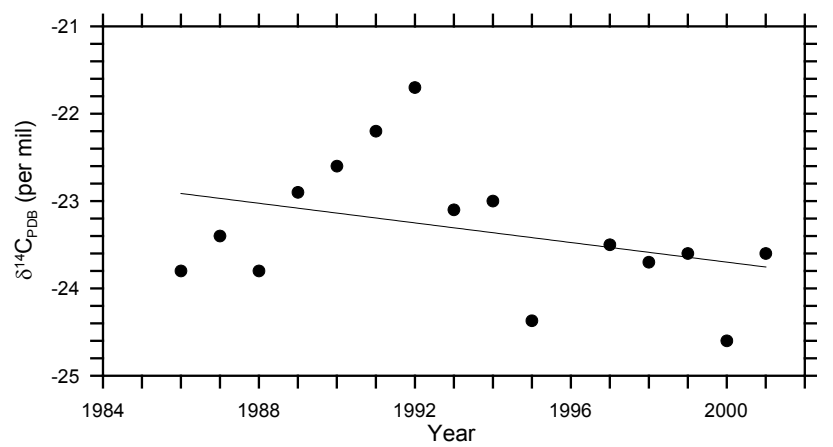

Fig. 9. Stable isotope composition of carbon in tree rings (Pinus radiata) from Arequipa, southern Peru. $\delta^{13} C_{P D B}$ measurement error is $\pm 0.1 \%$. 
from the air. By measuring the radiocarbon concentration in biospheric material (tree rings, leaves, grains, etc.) growing in the industrial and/or highly urbanized areas, where high emission of dead carbon is expected, it is possible to estimate the total emission of dead $\mathrm{CO}_{2}$. The calculation of this emission is possible by comparison of radiocarbon concentration in industrial areas with those in clean air. To estimate local decrease of radiocarbon concentration due to the Suess effect mathematical equations were used that included a relationship between carbon isotope composition and the concentration of carbon dioxide from fossil fuel combustion and the decreasing trend of radiocarbon content over time (Levin et al., 2003):

$$
\begin{aligned}
& \mathrm{c}_{\text {meas }}=\mathrm{c}_{\mathrm{BG}}+\mathrm{c}_{\text {bio }}+\mathrm{c}_{\text {foss }} \\
& \mathrm{c}_{\text {meas }} \delta^{13} \mathrm{C}_{\text {meas }}=\mathrm{c}_{\mathrm{BG}} \delta^{13} \mathrm{C}_{\mathrm{BG}}+\mathrm{c}_{\text {bio }} \delta^{13} \mathrm{C}_{\text {bio }}+\mathrm{c}_{\text {foss }} \delta^{13} \mathrm{C}_{\text {foss }} \\
& c_{\text {meas }}\left(\Delta^{14} C_{\text {meas }}+1000\right)=c_{B G}\left(\Delta^{14} C_{B G}+1000\right)+ \\
& c_{\text {bio }}\left(\Delta^{14} C_{\text {bio }}+1000\right)+c_{\text {foss }}\left(\Delta^{14} C_{\text {foss }}+1000\right)
\end{aligned}
$$

where:

$\mathrm{c}$ - concentration of $\mathrm{CO}_{2}(\mathrm{ppmV})$,

$\Delta^{14} \mathrm{C}$ - radiocarbon concentration (per mil),

$\mathrm{BG}$, bio, foss - atmospheric, biospheric and fossil fuel factors, respectively.

The background concentration of carbon dioxide in the atmosphere is the sum of two components. Global $\mathrm{CO}_{2}$ concentration in the atmosphere and its variations due the global the Suess effect along with biogenic factors are expressed as $\mathrm{c}_{\mathrm{BG}}$, and are referred to as the natural component. $\mathrm{CO}_{2}$ concentration due to the local effects is expressed as $\mathrm{c}_{\text {foss, }}$ and is referred to as the emission component. To estimate the concentration of carbon dioxide produced as fossil fuel emission, an assumption that $\Delta{ }^{14} \mathrm{C}$ value in fossil carbon is $-1000 \%$ was used. This reduces fossil factor in the Eq. 4.3, gives the formula:

$\mathrm{c}_{\text {foss }}=\mathrm{c}_{\mathrm{BG}} \cdot{ }^{14} \mathrm{~S}=\mathrm{c}_{\mathrm{BG}} \frac{\Delta^{14} \mathrm{C}_{\mathrm{BG}}-\Delta^{14} \mathrm{C}}{\Delta^{14} \mathrm{C}_{\mathrm{BG}}+1000}(\mathrm{ppmV})$

\section{Kraków}

Samples of annual rings of pine tree (Pinus sylvestris) collected in the city of Kraków (southern Poland), have been used to estimate the value of $\mathrm{c}_{\text {foss }}$ for the period 1983-2002. Obtained values correspond to the average concentration of $\mathrm{CO}_{2}$ emitted from combustion of fossil fuels, in the months from April to September (growing period). The highest values of $\mathrm{c}_{\text {foss }}$ were recorded in years $1986(10.6 \pm 1.3 \mathrm{ppmV}), 1983(9.9 \pm 1.7 \mathrm{ppmV})$, and 1988 $(9.1 \pm 1.2 \mathrm{ppmV})$ (Fig. 10). The lowest value throughout the period, $2.8 \pm 1.4 \mathrm{ppmV}$, was recorded in year 2000 . The average value of $\mathrm{c}_{\text {foss }}$, for the whole period between 1983 and 2003, is $6.18 \pm 0.51 \mathrm{ppmV}$. To compare, for the same location, in the work of Kuc and Zimnoch (1998) the seasonal average values of $\mathrm{c}_{\text {foss }}$ obtained for the period between 1983 and 1994 are $10 \mathrm{ppmV}$ for summer season (April-September) and $27 \mathrm{ppmV}$ for the winter season (October-March).

\section{Valladolid}

The values of the concentration of $\mathrm{CO}_{2}$ derived from fossil fuel combustion $\left(\mathrm{c}_{\mathrm{foss}}\right)$, have been calculated for the period of 1986-2007 (Fig. 10), based on the records of radiocarbon concentration in annual rings of pine tree (Pinus pinea), taken at the center of the city of Valladolid (central Spain). From each annual ring, early and late wood ring was separated and $\alpha$-cellulose was extracted. The values of the $c_{\text {foss }}$ in the early and late wood represent average concentration of $\mathrm{CO}_{2}$ in the months from January to June - early wood, and the months from July to December - late wood. Average values of $\mathrm{c}_{\text {foss }}$ for the period of 1986-2007 are respectively $5.08 \pm 0.33$ ppmV (early wood) and $4.70 \pm 0.36 \mathrm{ppmV}$ (late wood). The lowest $\mathrm{c}_{\text {foss }}$ value of $-0.4 \pm 1.3 \mathrm{ppmV}$ was obtained for the late wood ring formed in 1986, which is probably the value corresponding to the concentration of $\mathrm{CO}_{2}$ in the place from

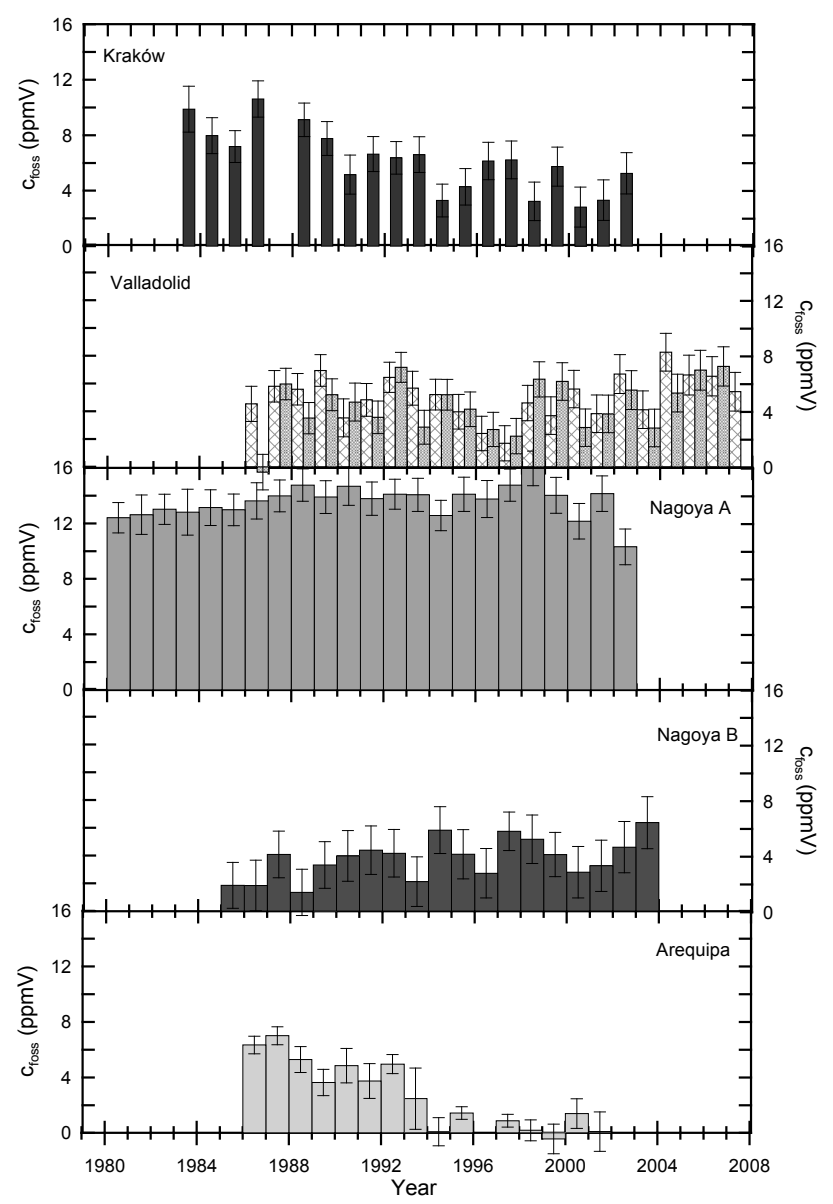

Fig. 10. Changes of fossil fuel component (Cfoss) of $\mathrm{CO}_{2}$ concentration calculated from radiocarbon concentration in annual tree rings from Krakow (southern Poland), Valladolid (central Spain), Nagoya (central Japan), Arequipa (Peru). 
where the trees were taken (nursery). In the remaining period the lowest values of $2.4 \pm 1.2 \mathrm{ppmV}$ (1996 EW), $2.7 \pm 1.2 \mathrm{ppmV}(1996 \mathrm{LW})$ and $1.7 \pm 1.3 \mathrm{ppmV}$ (1997 EW) and $2.2 \pm 1.3 \mathrm{ppmV}$ (1997 LW) were recorded.

\section{Nagoya}

Research using annual rings of pine tree (Pinus densiflora) from Nagoya city (central Japan) were conducted to determine the influence of $\mathrm{CO}_{2}$ emission from local sources on radiocarbon concentration in biospheric material. Samples were taken from two different places at the Nagoya University Campus. One was located near the road junction (dense traffic, Nagoya A) and the other close to the sport ground of the university, without sources of $\mathrm{CO}_{2}$ emission (Nagoya $\mathrm{B}$ ). The average value of $\mathrm{c}_{\text {foss }}$ were $13.5 \pm 1.5 \mathrm{ppmV}$ for the period of 1967-2002 for Nagoya A and $3.78 \pm 0.31 \mathrm{ppmV}$ for the period 19852003 for Nagoya B. The significant difference between those values result from different levels of $\mathrm{CO}_{2}$ emissions from fossil fuel use observed at each location. Since we do not expect any sources of $\mathrm{CO}_{2}$ emission at Nagoya B (like traffic, households, etc.), we can assume that the observed decrease of radiocarbon concentration in this place is caused by the mixing of air masses originating from various part of the city, including those which contain $\mathrm{CO}_{2}$ sources.

\section{Arequipa}

The set of values of radiocarbon concentration in Arequipa for the period between 1986-2003 has been obtained using a annual rings of pine tree (Pinus radiata). Those data were used to determine the $\mathrm{c}_{\text {foss }}$ component. Analysis based on measurement of carbon isotopic composition indicates that the main source of carbon emissions in this region are volcanoes. The highest values of $\mathrm{c}_{\text {foss }}$ component recorded for 1986-1992, correspond to the period in which a gradual increase in $\delta^{13} \mathrm{C}$ values can be observed. It is related to the $\mathrm{CO}_{2}$ of volcanic origin, for which $\delta^{13} \mathrm{C}=-1 \pm 2 \%$ (Gupta and Polach, 1985). Since year 1993 a gradual decrease in the $c_{\text {foss }}$ value can be observed, which can be related to decreasing $\mathrm{CO}_{2}$ emissions from the surrounding volcanoes. For the period between 1994 and 2001 the radiocarbon concentration in Arequipa is comparable to the average value of the concentration of this isotope for the entire southern hemisphere zone (SH zone, Hua and Barbetti, 2004). The average value of $\mathrm{c}_{\text {foss }}$ for the whole periods of the years $1983-2001$ is $2.79 \pm 0.64 \mathrm{ppmV}$ with the highest values of $6.3 \pm 0.6 \mathrm{ppmV}$ and $7.0 \pm 0.6 \mathrm{ppmV}$ in year 1986 and 1987 respectively. Different annual average values of $c_{\text {foss }}$ component during this period suggest that the amount of $\mathrm{CO}_{2}$ emitted by the local volcanoes over the years was not constant, with maximum of the emissions in the years 1986-1988.

\section{CONCLUSIONS}

The aim of this work was to establish an effective method for radiocarbon and carbon dioxide monitoring using annual tree rings. The AMS system gives possibilities to reduce the mass of samples to few milligrams and the material can be obtained using a hollow drill from living trees. By using this method, it is possible to obtain results for places, where concentration of radiocarbon decreases due to the Suess effect. The samples of annual tree rings used in this work were taken from living trees growing in the urban areas of big cities. To confirm the decrease of radiocarbon concentration caused by this effect in investigated sites, measurements of isotopic composition of carbon in annual tree rings were carried out. The results of these investigations lead to the following conclusions:

1) Radiocarbon concentrations in tree rings from Nagoya, Arequipa, Valladolid, Kraków and in samples of atmospheric carbon dioxide measured at Kraków during the analyzed period are systematically lower than those in "clean air" in each zone, due to $\mathrm{CO}_{2}$ emission from fossil fuel use.

2) Decrease of the radiocarbon concentrations depends on the value of $\mathrm{CO}_{2}$ emission from fossil fuel use and differs in time and place according to the total $\mathrm{CO}_{2}$ emission from fossil fuel use.

3) Radiocarbon concentration measured in tree rings from Kraków is similar to an average value obtained for atmospheric $\mathrm{CO}_{2}$ during the vegetation period. The vegetation period varies from place to place and is necessary to be taken into account to obtain reasonable results.

4) Results show that, with isotopic information recorded in tree rings, it is possible to reconstruct radiocarbon concentration in the past, and data like these can also be used for analytical calculation.

5) Temporal decrease of radiocarbon concentration can be described by using an exponential function fitted to the observed data for all analyzed periods. The functions yield an inverse value of the decay constant comparable to the estimates reported in the literature.

6) Using linear functions fitted to data, it is possible to predict the time that "natural" levels of $\Delta{ }^{14} \mathrm{C}$ will be reached, and the results obtained in this work are comparable with those reported in literature.

7) It is possible to calculate fossil fuel component $c_{\text {foss }}$ using data of radiocarbon concentration measured in tree rings. For this calculation, data of radiocarbon concentration and concentration of $\mathrm{CO}_{2}$ in "clean air" reported in literature can be used.

8) The differences in average values of $\mathrm{c}_{\text {foss }}$ between different places can be explained by different amounts of $\mathrm{CO}_{2}$ emitted into the atmosphere at each location. However, different condition at each location can also cause some difficulties in the process of air mass mixing. 
The results show that the assumption of homogeneous carbon content in atmosphere, made for modeling of the carbon cycle, is only approximation. In reality, disturbances may exist at some places due to emission of $\mathrm{CO}_{2}$ from fossil fuel use, and differences of carbon isotopic composition in the atmosphere can be observed. Because of a local character of those disturbances, it is not necessary to account for them in the modeling of the global carbon cycle. However, to better understand the effects caused by emission of $\mathrm{CO}_{2}$ from fossil fuel use, it is necessary to create a model of local carbon cycle on the basis of data of carbon isotopic composition, including mechanisms of air mass mixing at investigated locations. As a continuation of this work in future, more samples of tree rings will be analyzed to obtain more input data for modeling local carbon cycle.

\section{ACKNOWLEDGEMENTS}

Author would like to express his thanks to all staff of the GADAM Excellence Centre of Silesian University of Technology, Center for Chronological Research of Nagoya University and LIBRA Laboratory of University of Valladolid for their kind support. Special words of thanks are directed to Prof. Anna Pazdur and Prof. Toshio Nakamura for their contribution in my scientific career. To all my friends in Leibniz Labor in Kiel for creative working environment.

\section{REFERENCES}

[AEMet] Agencia Estatal de Meterología. Online on www.aemet.es/es/portada. Accessed 2010-11-15.

Craig H, 1957. Isotope standards for carbon and oxygen and correction factors for mass-spectrometric analysis scintillation counting. Nukcleonika 20(11-12): 1053-66.

Etheridge DM, Steele LP, Langenfeld RL, Franccy RJ, Barnola J-M and Morgan VI, 1996. Natural and anthropogenic changes in atmospheric $\mathrm{CO}_{2}$ over the last 1000 years from air in Antarctic ice firn. Journal of Geophysical Research 101(D2): 4115-4128, DOI 10.1029/95JD03410.

GLOBALVIEW-CO2, 2008. Cooperative Atmospheric Data Integration Project - Carbon Dioxide. CD-ROM, NOAA CMDL, Boulder, Colorado (Also available on Internet via www.esrl.noaa.gov/gmd/ccgg/globalview/index.html.

Green JW, 1963. Methods of Carbohydrate Chemistry. In: Whistler RL, ed., Methods in Carbohydrate. Chemistry, Acad.emic Press, New York: 9-21.

Gupta SK and Polach HA, 1985. Radiocarbon Dating Practices at $A N U$. Handbook, Radiocarbon Dating laboratory, Research School of Pacific Studies, ANU, Canberra: 173 pp.

Hua Q and Barbetti M, 2004. Review of Tropospheric Bomb 14C Data for Carbon Cycle Modeling and age Calibration Purposes. Radiocarbon 46(3): 1273-1298.

[JMA] Japan Meteorological Agency. Online on http://www.jma.go.jp. Accessed 2010-10-12.

Keeling CD and Whorf TP, 1994. Atmospheric $\mathrm{CO}_{2}$ records from sites in the SIO network. [in] Trends '93: A compendium of Data on Global Change, edited by T. Boden et al., 16-28, Carbon Dioxide Information Analysis Center (CDIAC), Oak Ridge National Laboratory (ORNL), Oak Ridge, Tennessee. (http://cdiac.esd.ornl.gov)
Keeling CD, Bocastow RB, Carter AF, Piper SC, Whorf TP, Heimann M, Mook WG and Roeloffzen H, 1989. A three-dimensional model of atmospheric $\mathrm{CO}_{2}$ transport based on observed winds: 1 . Analysis of observational data. In: Petersen DH, ed., Aspects of Climate Variability in the Pacific and Western Americas. Geophys. Monographs 55: 165-236.

Kitagawa H, Masuzawa T, Nakamura T and Matsumoto E, 1993. A batch preparation method for graphite targets with low level background for AMS ${ }^{14} \mathrm{C}$ measurements. Radiocarbon 35(2): 295-300.

Krajcar-Bronić I, Horvatinčić N and Obelić B, 1998. Two decades of environmental isotope records in Croatia, Reconstruction of the past and prediction of future level. Radiocarbon 40(1): 399-416.

Kuc T and Zimnoch M, 1998. Changes of the $\mathrm{CO}_{2}$ sources and sink in polluted urban area (southern Poland) over last decade, deriving from the carbon isotope composition. Radiocarbon 40(1): 417-23.

Kuc T, Rozanski K, Zimnoch M, Necki JM and Korus A, 2003. Anthropogenic emissions of $\mathrm{CO}_{2}$ and $\mathrm{CH}_{4}$ in an urban environment. Applied Energy 75(3-4): 193-203, DOI 10.1016/S03062619(03)00032-1.

Levin I and Hesshaimer V, 2000. Radiocarbon - a unique tracer of global carbon cycle dynamics. Radiocarbon 42(1): 69-80.

Levin I and Kromer B, 1997. Twenty years of high-precision atmospheric ${ }^{14} \mathrm{CO}_{2}$ observation at Schauinsland station, Germany. Radiocarbon 39(2): 205-218.

Levin I and Kromer B, 2004. The tropospheric ${ }^{14} \mathrm{CO}_{2}$ level in midlatitudes of the Northern Hemisphere (1959-2003). Radiocarbon 46(3): 1261-1272.

Levin I, Kromer B, Schmidt M and Sartorius H, 2003. A novel approach for independent budgeting of fossil fuel $\mathrm{CO}_{2}$ over Europe by ${ }^{14} \mathrm{CO}_{2}$ observation. Geopysical Research Letters 30(23): 2194-2198, DOI 10.1029/2003GL018477.

Levin I, Bösinger R, Bonani G, Francey RJ, Kromer B, Mnich KO, Suter M, Trivett NBA and Wölfli W, 1992. Radiocarbon in atmospheric carbon dioxide and methane: Global distribution and trends. In: Taylor RE, Long A and Kra RS, eds., Radiocarbon After Four Decades: An Interdisciplinary Perspective. New York, SpringerVerlag: 503-518.

Levin I, Kromer B, Schoch-Fischer H, Bruns M, Münnich M, Berdau D, Vogel JC and Münnich KO, 1994. ${ }^{14} \mathrm{CO}_{2}$ records from two sites in central Europe. In: Boden TA. Kaiser DP, Sepanski RJ and Stoss FW, eds., Trends 93-A Compendium of Data on Global Change and online updates. Oak Ridge, Tennessee, USA: Carbon Dioxide Information Analysis Center, Oak Ridge National Laboratory: 203-22. http://cdiac.esd.ornl.gov/trends/co2/cent.htm.

Levin I, Kromer B and Francey RJ, 1999. Continuous measurements of ${ }^{14} \mathrm{C}$ in atmospheric $\mathrm{CO}_{2}$ at Cape Grim, 1995-1996. In: Grass JL, Derek N, Tindale NW and Dick AL, eds., Baseline Atmospheric Program Australia1996. Melbourne: Bureau of Meteorology and CSIRO Atmospheric Research: 89-90.

Linacre E and Geerts B, 1997. Climates and Weather Explained. London, Routledge: $653 \mathrm{pp}$.

Marland G, Boden TA, Andres RJ, Brenkert AL and Johnston CA 1999. Global, regional, and national fossil fuel $\mathrm{CO}_{2}$ emission. In: Trends: A Compendium of Data on Global Change. Carbon Dioxide Information Analysis Center (CDIAC), Oak Ridge National Laboratory (ORNL), Oak Ridge, Tennessee. (http://cdiac.esd.ornl.gov).

McNeely R, 1994. Long-term environmental monitoring of ${ }^{14} \mathrm{C}$ levels in the Ottava region. Environmental International 20(5): 675-679, DOI 10.1016/0160-4120(94)90013-2.

Meijer HAJ, van der Plicht J, Gislefoss JS and Nydal R, 1995. Comparing long-term atmospheric ${ }^{14} \mathrm{C}$ and ${ }^{3} \mathrm{H}$ records near Groningen, the Netherlands with Fruholmen, Norway and Izaña, Canary Islands ${ }^{14} \mathrm{C}$ stations. Radiocarbon 37(1): 39-50.

Mook WG and van der Plicht J, 1999. Reporting ${ }^{14} \mathrm{C}$ activities and concentrations. Radiocarbon 41(3): 227-240.

Muraki Y, Masuda K, Arslanov KhA, Toyoizumi H, Kato M, Naruse Y and Nishiyama T, 2001. Measurement of radiocarbon content in leaves from some Japanese sites. Radiocarbon 42(2B): 695-701. 
Muraki Y, Kocharov G, Nishiyama T, Naruse Y, Murata T, Masuda K and Arslanov KhA, 1998. The new Nagoya Radiocarbon Laboratory. Radiocarbon 40(1): 177-182.

Nakamura T, Niu E, Oda H, Ikeda A, Minami M, Takahashi H, Adachi M, Pals L, Gottdang A and Suya N, 2000. The HVEE Tandetron AMS system at Nagoya University. Nuclear Instruments and Methods in Physics Research B 172(1-4): 52-57, DOI 10.1016/S0168-583X(00)00398-0.

Nydal R, 1968. Further investigation on the transfer of radiocarbon in nature. Journal of Geophysical Research 73(12): 3617-3635, DOI 10.1029/JB073i012p03617.

Nydal R and Lövseth K, 1996. Carbon-14 measurement in atmospheric $\mathrm{CO}_{2}$ from Northern and Southern Hemisphere sites, 1962-1993. Oak Ridge, Tennessee, USA: Carbon Dioxide Information Analysis Center-World Data Center-A for Atmospheric Trace Gases (http://cdiac.esd.ornl.gov).

Oeschger H, Siegenthaler U, Schotterer U and Gugelmann A, 1975. A box diffusion model to study the carbon dioxide exchange in nature. Tellus 27(2): 168-192.

Pazdur A, Korput S, Fogtman M, Szczepanek M, Hałas S, Krąpiec E and Szychowska-Krąpiec E, 2005. Carbon-13 in $\alpha$-cellulose of oak latewood (Jędrzejów, southern Poland) during the Maunder minimum. Geological Quarterly 49(2): 165-72.

Pazdur A, Nakamura T, Pawełczyk S, Pawlyta J, Piotrowska N, Rakowski AZ, Sensuła B and Szczepanek M, 2007. Carbon isotopes in tree rings: Climate and Human activities in the last 400 years. $R a$ diocarbon 49(2): 775-788.

Petit JR, Jouzel J, Raynaud D, Barkov NI, Barnola JM, Basile I, Bender M, Chappellaz J, Davis J, Delaygue G, Delmotte M, Kotlyakov VM, Legrand M, Lipenkov V, Lorius C, Pépin L, Ritz C, Saltzman E and Stievenard M, 1999. Climate and Atmospheric History of the Past 420,000 years from the Vostok Ice Core, Antarctica. Nature 399(6735): 429-436, DOI 10.1038/20859.

Rakowski AZ, 2010. Metoda radioweglowa w pomiarach udziatu $\mathrm{CO}_{2}$ emitowanego do atmosfery ze spalania paliw kopalnych (Radiocarbon method in measurement of fossil fuel component of carbon dioxide in the atmosphere). Wydawnictwo Politechniki Śląskiej. ISBN 978-83-7335-688-7: 120pp (in Polish).
Rakowski AZ, Pawełczyk S and Pazdur A, 2001. Changes of ${ }^{14} \mathrm{C}$ concentration in modern trees from Upper Silesia region, Poland. $R a-$ diocarbon 43(2B): 679-689.

Rakowski A, Kuc T, Nakamura T and Pazdur A, 2004a. Radiocarbon Concentration in the Atmosphere and Modern Tree Rings in the Kraków Area, Southern Poland. Radiocarbon 46(2): 911-916.

Rakowski AZ, Nakamura T and Pazdur A, 2004b. Changes of radiocarbon concentration in modern wood from Nagoya, central Japan. Nuclear Instruments and Methods in Physics Research Section B 223-224: 507-510, DOI 10.1016/j.nimb.2004.04.095.

Rakowski AZ, Kuc T, Nakamura T and Pazdur A, 2005. Radiocarbon concentration in urban area. Geochronometria 24: 63-68.

Rakowski AZ, Nakamura T and Pazdur A, 2008. Variations of anthropogenic $\mathrm{CO}_{2}$ in urban area deduced by radiocarbon concentration in modern tree rings. Journal of Environmental Radioactivity 99(10): 1558-1565, DOI 10.1016/j.jenvrad.2007.12.007.

Rakowski AZ, Nakamura T, Pazdur A, Charo E, Gutierrez-Villanueva JL and Piotrowska N, 2010. Radiocarbon concentration in modern tree rings from Valladolid, Spain. Nuclear Instruments and Methods In Physics Research Section B-Beam Interactions with Materials and Atoms 268(7-8): 1110-1112, DOI 10.1016/j.nimb.2009.10.111

Schmidt M, Graul R, Sartorius H and Levin I, 2003. The Schauinsland $\mathrm{CO}_{2}$ record: 30 years of continental observations and their implications for the variability of the European $\mathrm{CO}_{2}$ budget. Journal of Geophysical Resaearch 108(D19): 4619-4625, DOI 10.1029/2002JD003085.

Stuiver M and Polach HA, 1977. Reporting of 14C data. Radiocarbon 19: $355-363$

Stuiver M and Quay PD, 1981. Atmospheric ${ }^{14} \mathrm{C}$ changes resulting from fossil fuel $\mathrm{CO}_{2}$ release and cosmic ray flux variability. Earth and Planetary Science Letters 53(3): 349-362, DOI 10.1016/0012821X(81)90040-6.

Suess HE, 1955. Radiocarbon concentration in modern wood. Science 122: 415-417, DOI 10.1126/science.122.3166.415-a.

Telegadas K, 1971. The seasonal atmospheric distribution and inventories of excess carbon-14 from March 1955 to July 1969. US Atomic Energy Commission Report HASL-243. 